\section{Medium-term Storage of Apricot Shoot Tips In Vitro by Minimal Growth Method}

\author{
O. Pérez-Tornero, F. Ortín-Párraga, J. Egea, and L. Burgos ${ }^{1}$ \\ Departamento de Mejora y Patología Vegetal, Centro de Edafología y Biología \\ Aplicada del Segura (C.S.I.C.), Apartado de Correos 4.195, 30.080 Murcia, \\ Spain
}

Additional index words. micropropagation, Prunus armeniaca, $N^{6}$-benzyladenine, temperature, auxin, cytokinin

\begin{abstract}
Apricot (Prunus armeniaca L. cv. 'Helena') shoots grown on a proliferation medium containing $3 \%$ sucrose, $0.4 \mathrm{mg} \cdot \mathrm{L}^{-1}$ benzyladenine $(B A)$, and $0.04 \mathrm{mg} \cdot \mathrm{L}^{-1}$ indolebutyric acid (IBA) and solidified with $0.6 \%$ agar were stored at three different temperatures in the dark for up to 24 weeks. All shoots remained viable for 24 weeks when stored at $3{ }^{\circ} \mathrm{C}$, while at $14^{\circ} \mathrm{C}$ the percentage of survival decreased quickly after 12 weeks of storage. At $7^{\circ} \mathrm{C}$, percentage of survival started to decline after 18 weeks of storage. Shoots stored at $3^{\circ} \mathrm{C}$ had the highest regeneration rates and shoot lengths following transfer to standard proliferation conditions. This temperature also had a beneficial effect on shoot proliferation during the first 12 to 18 weeks of the experiment.
\end{abstract}

Fruit tree germplasm is usually conserved in orchards. This system requires a large land area and a great deal of labor for growing plants safely. The use of in vitro repositories for the maintenance of valuable plant genotypes or virus-free plantlets offers a number of advantages over conventional methods. Greenhouse space and maintenance are reduced, and the stored material is protected from insect pests and pathogens and can be micropropagated rapidly when desired. The successful use of low temperatures for long-term minimal growth storage of temperate fruit trees has been reported for Prunus (Dorion et al., 1991; Marino et al., 1985; Sauer, 1985), Malus (Orlikowska, 1992), and Pyrus (Oka and Niino, 1997), among others.

The main objective of the minimal growth procedure is to extend the subculturing interval from the normal 2 to 6 weeks to a much longer period (e.g., 3 to 12 months). Several approaches can be used to achieve this goal, of which incubation at reduced temperature and low light intensity (or in darkness) are the most common. Minimal growth storage is a very simple technique that allows storage of plants in vitro for periods ranging from 6 months to 5 years, depending on species. These stored plants can be micropropagated rapidly when desired.

\footnotetext{
Received for publication 8 Feb. 1999. Accepted for publication 24 May 1999. We thank Dr. Craig A. Ledbetter of the Horticultural Crops Research Laboratory, Agricultural Research Service, U.S. Dept. of Agriculture, Fresno, Calif., for kindly providing the initial in vitro explants of 'Helena'. The cost of publishing this paper was defrayed in part by the payment of page charges. Under postal regulations, this paper therefore must be hereby marked advertisement solely to indicate this fact.

'E-mail address: burgos@natura.cebas.csic.es
}

To our knowledge there is no information on preservation of apricot (Prunus armeniaca L.) germplasm by in vitro slow-growth storage. The aim of this study was to determine the effect of temperature on regrowth of stored apricot plantlets, measured as shoot production and shoot length during repropagation.

\section{Materials and Methods}

Initial shoot cultures of apricot cv. 'Helena' were kindly provided by Dr. Craig A. Ledbetter. Shoots were propagated in a proliferation medium containing $\left(\mathrm{mg} \cdot \mathrm{L}^{-1}\right): 184$ $\mathrm{NH}_{4} \mathrm{NO}_{3}, 1364 \mathrm{Ca}\left(\mathrm{NO}_{3}\right)_{2} \cdot 4 \mathrm{H}_{2} \mathrm{O}, 928 \mathrm{KNO}_{3}$, 87.4 $\mathrm{Mg}\left(\mathrm{NO}_{3}\right)_{2} \cdot 6 \mathrm{H}_{2} \mathrm{O}, 739.4 \mathrm{MgSO}_{4} \cdot 7 \mathrm{H}_{2} \mathrm{O}$, $107.4 \mathrm{KH}_{2} \mathrm{PO}_{4}, 4.8 \mathrm{H}_{3} \mathrm{BO}_{3}, 0.25 \mathrm{CuSO}_{4} \cdot 5 \mathrm{H}_{2} \mathrm{O}$, $33.5 \mathrm{MnSO}_{4} \cdot \mathrm{H}_{2} \mathrm{O}, 0.39 \mathrm{Na}_{2} \mathrm{MoO}_{4} \cdot 2 \mathrm{H}_{2} \mathrm{O}, 17$ $\mathrm{ZnSO}_{4} \cdot 7 \mathrm{H}_{2} \mathrm{O}, 33.8 \mathrm{FeSO}_{4} \cdot 7 \mathrm{H}_{2} \mathrm{O}, 50.26 \mathrm{Na}_{2}-$ EDTA $2 \mathrm{H}_{2} \mathrm{O}, 2$ glycine, 100 myoinositol, 1 nicotinic acid, and 2 thiamine. Also, $3 \%$ sucrose, $0.6 \%$ agar (Hispanlab, S.A., Madrid, Spain), and $1.78 \mu \mathrm{M} N^{6}$ BA and $0.20 \mu \mathrm{M}$ IBA were added to the medium.

Storage of shoots. About 500 shoots 15 $\mathrm{mm}$ long were obtained from proliferated shoot cultures and placed in $500-\mathrm{mL}$ glass vials containing $100 \mathrm{~mL}$ of the apricot proliferation medium. The vials were covered with nonvented closures, sealed with plastic film, and incubated at 3,7 , or $14^{\circ} \mathrm{C}$ in the dark for 6,12 , 18 , or 24 weeks. Each treatment consisted of three replicates with 12 shoots per vial.

Repropagation of shoots from stored shoot cultures. After each storage period, the length of the shoots was measured and survival determined based on the number of shoots with green terminal and/or lateral buds. The live shoots were then trimmed to a length of 10 to $15 \mathrm{~mm}$ by removing the basal portion if necessary, and cultured at $23{ }^{\circ} \mathrm{C}$ under $16-\mathrm{h}$ illumination with white fluorescent lights $(55$ $\mu \mathrm{mol} \cdot \mathrm{s}^{-1} \cdot \mathrm{m}^{-2}$ ) followed by $8 \mathrm{~h}$ at $21^{\circ} \mathrm{C}$ in the dark for 3 weeks on the proliferation medium. The number of new shoots produced and their average length were then recorded.

\section{Results and Discussion}

Survival of 'Helena' shoot tips stored at 3 ${ }^{\circ} \mathrm{C}$ remained near $100 \%$ (Fig. 1). Those stored at $14{ }^{\circ} \mathrm{C}$ grew more than at the other temperatures; survival rate fell slightly 12 weeks after the onset of the experiment (Fig. 1), then decreased rapidly; none survived after 24 weeks. Viability of those stored at $7{ }^{\circ} \mathrm{C}$ fell slightly at 24 weeks.

The growth rate of shoots was slow at $3{ }^{\circ} \mathrm{C}$, but increased with temperature (Fig. 1). Shoots stored at $14^{\circ} \mathrm{C}$ became etiolated, brown, and shrunken, while most shoots stored at $3^{\circ} \mathrm{C}$ and $7^{\circ} \mathrm{C}$ remained healthy.

The temperature of storage significantly affected all variables recorded $(P \leq 0.05)$. The length of storage and length of storage $\times$ temperature interaction were significant $(P \leq 0.05)$ for the number of new shoots and the productivity (number of shoots $\times$ the average length), but did not significantly affect the average shoot length.

The number of new shoots produced, after reculturing the stored shoots for 3 weeks in normal conditions, decreased with the time they were stored at 7 and $14{ }^{\circ} \mathrm{C}$. The $14{ }^{\circ} \mathrm{C}$ plants produced the fewest shoots during the experiment. When shoots were stored at $3{ }^{\circ} \mathrm{C}$ the number of shoots produced followed a quadratic function, making it possible to predict maximum shoot production when stored 15 weeks at $3^{\circ} \mathrm{C}$ (Fig. 2).

Average shoot length was affected significantly only by storage temperature $(P \leq 0.05)$. New shoots after 3 weeks in standard culture were smallest at $14{ }^{\circ} \mathrm{C}(15.4 \pm 0.6 \mathrm{~mm}$ averaged over all treatments); those produced by shoots stored at 3 and $7{ }^{\circ} \mathrm{C}$ were similar (18.5 \pm 0.6 and $19.5 \pm 1.6 \mathrm{~mm}$, respectively, averaged over all treatments).

Productivity is a useful variable reflecting the general behavior of the plants in vitro. Productivity paralleled the number of shoots (Fig. 2). The productivity of shoots stored at 7 and $14{ }^{\circ} \mathrm{C}$ and recultured for 3 weeks decreased with time of storage, while at $3{ }^{\circ} \mathrm{C}$ maximum productivity occurred at 15 weeks. The overall average value obtained for the productivity $(55.1 \pm 2.1 \mathrm{~mm})$ was significantly higher ( $P \leq 0.05$, according to a Dunnett's test) at $3{ }^{\circ} \mathrm{C}$ than for a control sample that was never stored but cultured in standard conditions (average productivity $38.9 \pm 2.6 \mathrm{~mm}$ ).

The results obtained in this study demonstrated that 'Helena' shoots stored at $3{ }^{\circ} \mathrm{C}$ could survive and regenerate shoots for at least 6 months without subculture. Low temperatures may be critical for minimal growth; Oka and Niino (1997) reported that pear (Pyrus sp.) shoots died after a short time at $0^{\circ} \mathrm{C}$. However, Marino et al. (1985) were able to keep vigorous Prunus shoot cultures up to 10 months at $-3{ }^{\circ} \mathrm{C}$ in the dark, and Dorion et al. (1994) stored peach [Prunus persica $($ L.) Batsch.] shoots for 8 months and peach $\mathrm{x}$ almond (Prunus dulcis L.) hybrid shoots for 10 months at $0{ }^{\circ} \mathrm{C}$. 


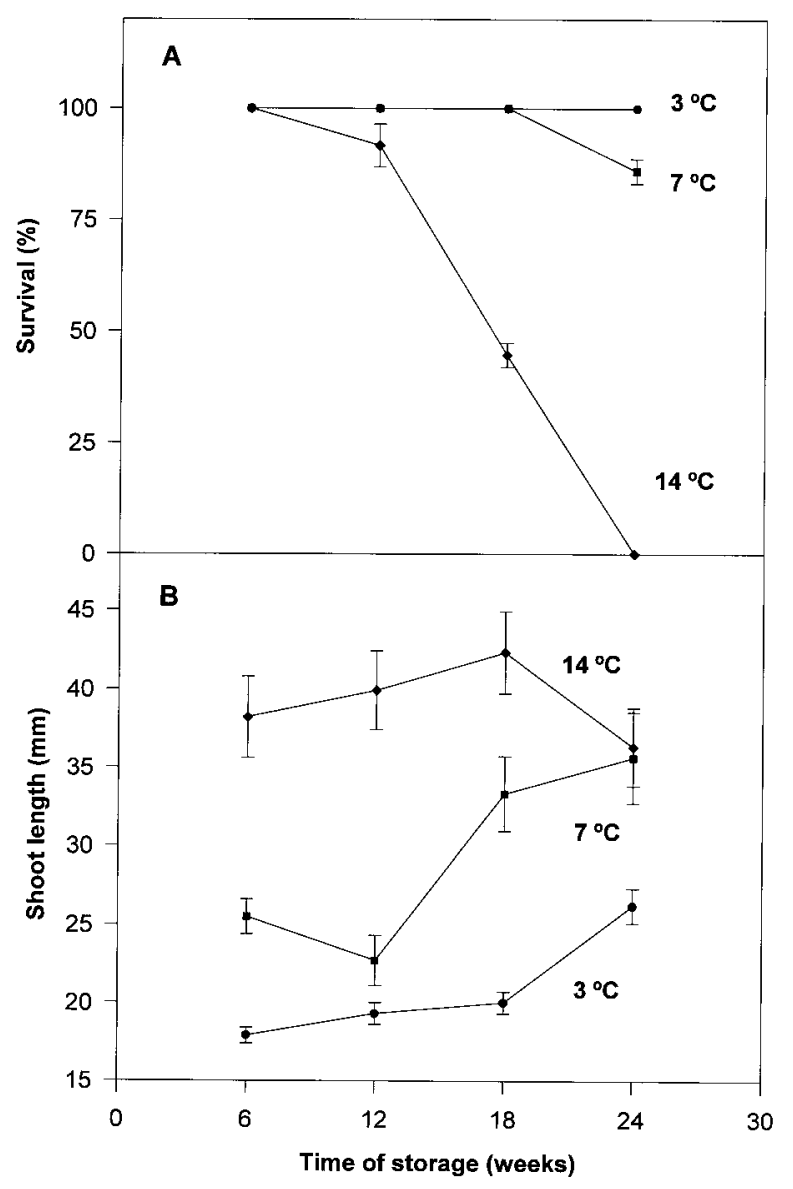

Fig. 1. (A) Survival and (B) shoot length of apricot shoots after storage at three temperatures for $6,12,18$, or 24 weeks. Data are means from three replications of 12 explants each. Vertical bars represent standard errors.

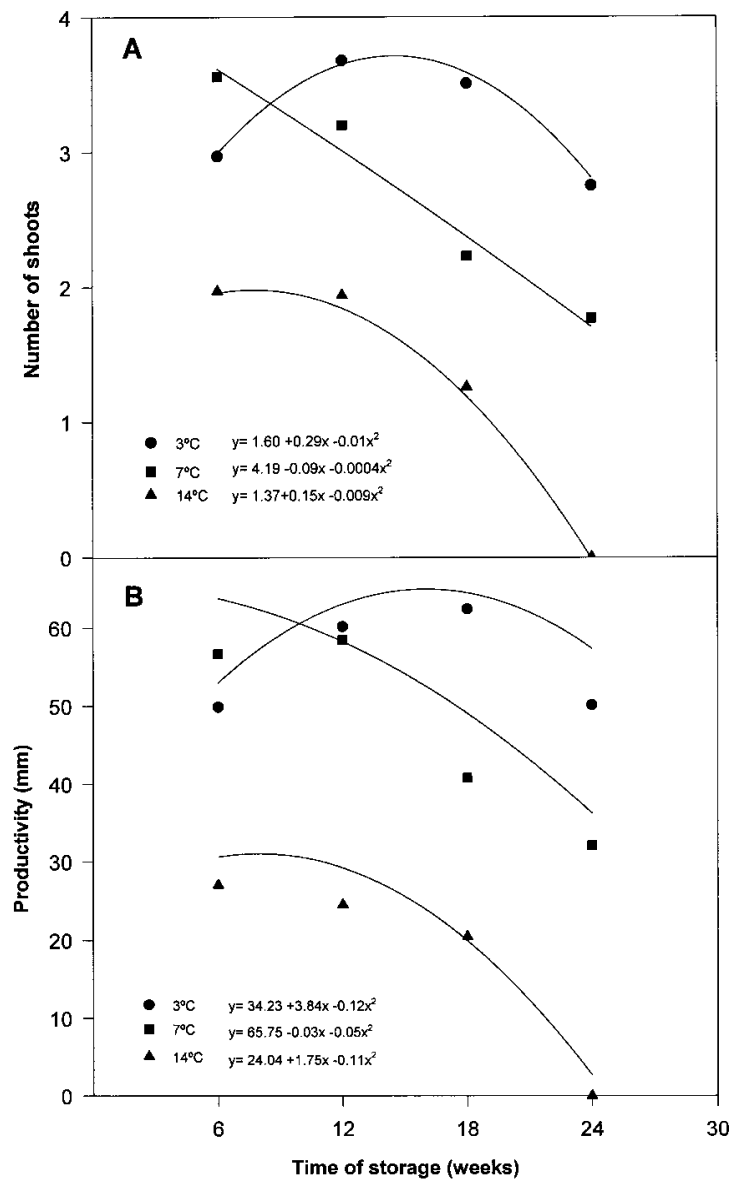

Fig. 2. (A) Average number of new shoots produced by stored plantlets, and $(\mathbf{B})$ average productivity (number of regenerated shoot $\times$ their average length) and polynomial trend comparisons after storage at three temperatures for $6,12,18$, or 24 weeks and repropagation for 3 weeks in the growth room. Linear models for both number of shoots and productivity were significant $(P \leq 0.001)$ with $R^{2}$ of 0.90 and 0.92 , respectively.
Survival at 7 and $14{ }^{\circ} \mathrm{C}$ decreased with length of storage at a rate similar to shoot elongation at these temperatures, suggesting that depletion of nutrients in the medium paralleled growth.

Light of low intensity may improve survival. Better results were obtained when pear shoots were stored under white fluorescent lamps of 2000 to 4000 lux for $8 \mathrm{~h} \cdot \mathrm{d}^{-1}$ than when they were stored in the dark (Oka and Niino, 1997).

The beneficial effects of storage at $3{ }^{\circ} \mathrm{C}$ on number of shoots and productivity during the first weeks of regrowth may have been related to dormancy requirements. Other apricot cultivars also perform better in vitro after storage for some time at $3{ }^{\circ} \mathrm{C}$.

Chemicals that retard growth or make cells less susceptible to cold may prolong the life of shoot cultures; paclobutrazol $\left\{( \pm)-\left(R^{*}, R^{*}\right)-\beta\right.$ [(4-chlorophenyl)methyl]- $\alpha$-(1,1-dimethyl)$1 H$-(1,2,4-triazole)-1-ethanol $\}$ improved recovery of Prunus avium L. shoots (Snir, 1988).
We detected no harmful effects when other apricot cultivars were stored at $3^{\circ} \mathrm{C}$ for periods of $\approx 3$ months. Normal proliferation rates were obtained after storage and shoots could be rooted and acclimatized.

Shoot regrowth and shoot length were highest when shoots were stored at $3{ }^{\circ} \mathrm{C}$ for 3 to 6 months and then transferred to standard proliferation conditions. This temperature increased shoot proliferation over nonstored controls during the first 12 to 18 weeks of the experiment.

Minimal growth storage is clearly useful for the preservation of apricot clones required as stocks for continued propagation in vivo or in vitro. It also increases flexibility in micropropagation and overcomes temporary difficulties in production.

\section{Literature Cited}

Dorion, N., M. Kadri, and C. Bigot. 1991. In vitro preservation at low temperature of rose plantlets usable for direct acclimatization. Acta Hort. 298:335-340.

Dorion, N., J.L. Regnard, I. Serpette, and C. Bigot. 1994. Effects of temperature and hypoxic atmosphere on preservation and further development of in vitro shoots of peach ('Armking') and peach x almond hybrid ('GF677'). Scientia Hort. 57:201-213.

Marino, G., P. Rosati, and F. Sagrati. 1985. Storage of in vitro cultures of Prunus rootstocks. Plant Cell Tiss. Org. Cult. 5:73-78.

Oka, S. and T. Niino. 1997. Long term storage of pear (Pyrus sp.) shoot cultures in vitro by minimal growth method. Jpn. Agr. Res. Quart. $31: 1-7$.

Orlikowska, T. 1992. Effect of in vitro storage at $4{ }^{\circ} \mathrm{C}$ on survival and proliferation of two apple rootstocks. Plant Cell, Tiss. Org. Cult. 31:17.

Sauer, A. 1985. In vitro propagation of Prunus avium $\mathrm{L}$. and storage of in vitro derived plantlets. Acta Hort. 169:351.

Snir, I. 1988. Influence of paclobutrazol on in vitro growth of sweet cherry shoots. HortScience 23:304-305. 